\title{
Optimization of ultrasound-assisted extraction of sheep abomasum protein concentrates by response surface methodology and evaluation of their properties
}

\author{
Liu BING ${ }^{1,2,3}$ (D), Aisa HAJI AKBER ${ }^{1,3,4}$, Yili ABULIMITI ${ }^{1,3,4 *}$
}

\begin{abstract}
The aim of this study was to extract sheep abomasum protein concentrates (SAPC) by ultrasound-assisted extraction (UAE) and to investigate the properties of SAPC. Response surface methodology and Box-Behnken design were applied to determine the optimal parameters for UAE. The maximum water-soluble protein concentration was $320.5 \mathrm{mg}$ protein $/ \mathrm{g}$ dry raw material under the optimal conditions with ultrasonic treatment time of $28 \mathrm{~min}$, ultrasonic power of $450 \mathrm{~W}$, liquid/solid ratio of $25 \mathrm{~mL} / \mathrm{g}$, and $\mathrm{pH}$ of 10. Compare with conventional extraction method (CEM), the UAE not only provided the higher protein concentration and yield but also required much shorter extraction times. Additionally, the SAPC obtained by UAE demonstrated better solubility, emulsifying properties, foaming properties and oil holding capacity as compared to CEM. However, use of the UAE method did not significantly increase the water holding capacity of SAPC.
\end{abstract}

Keywords: sheep abomasum; protein concentrates; ultrasound-assisted extraction; response surface methodology; functional properties.

Practical Application: Based on its functional properties, SAPC obtained using UAE may have potential uses as pharmaceutical or nutritional ingredients in various food or medicines.

\section{Introduction}

Large amounts of sheep abomasum (SA) are generated as a by-product of the sheep meat industry (Toldrá et al., 2012; Martínez-Alvarez et al., 2015). Efforts have been made to convert those by-products to a new source of functional ingredients or novel products due to their high nutritional value and good bioavailability (Mora et al., 2014; Queiroz et al., 2017). Several earlier studies have reported that SA is rich in proteins and numerous other nutrients (Li \& Chen, 1987; Chen, 1982; Zhao, 2011). Therefore, it is assumed that sheep abomasum protein concentrates (SAPC) are valuable animal proteins that can be applied for functional or pharmaceutical products. Freeze-melting and stirring (Zhang, 2003; Zhao, 2011) are conventional extraction methods used for SAPC extraction, but these methods are time-consuming and can adversely affect bioactivity or pharmaceutical values (Jodayree et al., 2012; Tang et al., 2015). Therefore, to gain SAPC, a more environmentally friendly and highly efficient extraction process should be applied.

Recent years, ultrasonic-assisted extraction (UAE) has been used to extract proteins from various sources including rice bran (Chittapalo \& Noomhorm, 2009), rapeseed protein (Dong et al., 2011), porcine placenta (Tang et al., 2015), and chicken egg shell membrane (Jain \& Anal, 2016). Compared with conventional methods, the UAE approach is time-reducing, and allows easy operation, high extraction yield, and low energy consumption
(Rocha et al., 2017; Li et al., 2017). However, the application of UAE for the extraction of protein concentrates from sheep abomasum has not been reported.

In this study, response surface methodology (RSM) and a four-variable, three-level Box-Behnken design (BBD) were used for the optimization of four parameters of UAE including extraction time, ultrasound power, liquid/solid ratio, and $\mathrm{pH}$ for the highest water-soluble protein concentration (WSPC). Additionally, the yield, chemical composition, and functional properties of SAPC obtained by conventional extraction method (CEM) and UAE were determined and compared. This is the first study to determine the appropriate protocol to prepare SAPC, and the results should facilitate utilization of these industrial by-products.

\section{Materials and methods}

\subsection{Materials and reagents}

Fresh SA was obtained from Urumqi slaughter house (Xinjiang, China), and rinsed into cold water to remove connective tissue and the residue in stomach, then cut into pieces and immediately frozen at $-80{ }^{\circ} \mathrm{C}$ for $24 \mathrm{~h}$. The frozen sample was lyophilized (FDU-2100, EYELA), crushed, defatted with ligarine, and stored in polyethylene bags at $-20{ }^{\circ} \mathrm{C}$ until use. All reagents were of

Received 16 Nov., 2017

Accepted 26 Nov., 2018

${ }^{1}$ Chinese Academy of Sciences - CAS, Xinjiang Technical Institute of Physics and Chemistry - XTIPC, Urumqi, China

${ }^{2}$ University of Chinese Academy of Sciences - UCAS, Beijing, China

${ }^{3}$ The Key Laboratory of Plant Resources and Chemistry of Arid Zone, Chinese Academy of Sciences - CAS, Xinjiang Technical Institute of Physics and Chemistry - XTIPC, Urumqi, China

${ }^{4}$ State Key Laboratory Basis of Xinjiang Indigenous Medicinal Plants Resource Utilization, Chinese Academy of Sciences - CAS, Xinjiang Technical Institute of Physics and Chemistry - XTIPC, Urumqi, China

${ }^{*}$ Corresponding author: abu@ms.xjb.ac.cn 
analytical grade. The WSPC was measured by Pierce ${ }^{\circledR}$ BCA Protein Assay Kit (Thermo Scientific).

\subsection{Preparation of sheep abomasum protein concentrates}

SAPC samples were prepared by two different methods, the CEM and UAE methods. For UAE, this method was performed in an ultrasonic generator (JY98-IIIN Ningbo Scientz Biotechnology Co. Ltd., China). In short, defatted SA were extracted with alkaline solution at the established $\mathrm{pH}$, ultrasound power and time. Then, the mixture was centrifuged at $12,000 \mathrm{r} / \mathrm{min}$ for $10 \mathrm{~min}$ at $4{ }^{\circ} \mathrm{C}$. The pellet was discarded and the supernatant was collected, dialyzed and the WSPC was determined. Ammonium sulfate was added to the supernatant to reach $60 \%$ saturation and stirring for $3 \mathrm{~h}$, then centrifuged at $10,000 \mathrm{r} / \mathrm{min}$ for $20 \mathrm{~min}$. The precipitate was washed by de-ionized water, re-dissolved and dialyzed for $24 \mathrm{~h}$ against de-ionized water. The solution was lyophilized and kept in a polyethylene bag at $-20{ }^{\circ} \mathrm{C}$ until use.

As a comparison, CEM method was performed. Defatted SA ( $1.0 \mathrm{~g})$ were homogenized with alkaline solution $(\mathrm{pH}=10$, liquid/solid ratio = 25) and then stirred under ice bath for $240 \mathrm{~min}$. Then the mixture was processed with the same protocol as UAE.

\subsection{Experimental design and statistical analysis}

RSM and BBD with four variables and three levels were used to optimize UAE parameters. The extraction time $\left(\mathrm{X}_{1}\right)$, ultrasound power $\left(\mathrm{X}_{2}\right)$, liquid/solid ratio $\left(\mathrm{X}_{3}\right)$ and $\mathrm{pH}\left(\mathrm{X}_{4}\right)$ were chosen as the independent variables. The WSPC was determined as the response of the design experiments (Y). Based on the single-factor experiments (data not shown), $\mathrm{X}_{1}$ (20,30 and $40 \mathrm{~min}$ ), $\mathrm{X}_{2}(200,400$ and $600 \mathrm{~W}), \mathrm{X}_{3}(20,25$ and $30 \mathrm{~mL} / \mathrm{g})$ and $\mathrm{X}_{4}(8,9$ and 10) were determined as critical levels with significant effect on protein extraction. Each independent variable and relative levels are given in Table 1. Twenty-four factorial points and five replicates of central point in the total 29 experiments were performed. The experimental results were analyzed using RSM algorithm and were fitted to the following predictive quadratic polynomial Equation 1:

$Y=\beta_{0}+\sum_{i=1}^{4} \beta_{i} X_{i}+\sum_{i=1}^{4} \beta_{i i} X_{i}^{2}+\sum_{i=1}^{3} \sum_{j=i+1}^{4} \beta_{i j} X_{i} X_{j}$

Where $\mathrm{Y}_{\mathrm{i}}$ is the response variable, $\beta_{0}$ is the model constant, $\beta_{\mathrm{i}}$ is the linear terms, $\beta_{\mathrm{ii}}$ are the squared terms, $\beta_{\mathrm{ij}}$ is the interaction terms, and $\mathrm{X}_{\mathrm{i}}$ and $\mathrm{X}_{\mathrm{j}}$ are independent variables.

Table 1. Box-Behnken design with experimental responses for water-soluble protein concentration (WSPC).

\begin{tabular}{|c|c|c|c|c|c|}
\hline Run & $\mathrm{X}_{1}$ :Extraction time $(\mathrm{min})$ & $\mathrm{X}_{2}:$ Ultrasonic power $(\mathrm{W})$ & $\mathrm{X}_{3}$ :Liquid/solid ratio $(\mathrm{mL} / \mathrm{g})$ & $\mathrm{X}_{4}: \mathrm{pH}$ & $\mathrm{WSPC}^{*}(\mathrm{mg} / \mathrm{g})$ \\
\hline 1 & 40 & 600 & 25 & 9 & $286.1 \pm 13.7$ \\
\hline 2 & 20 & 400 & 25 & 8 & $235.2 \pm 9.2$ \\
\hline 3 & 20 & 400 & 20 & 9 & $259.6 \pm 7.8$ \\
\hline 4 & 30 & 600 & 20 & 9 & $276.7 \pm 11.6$ \\
\hline 5 & 30 & 200 & 30 & 9 & $246.4 \pm 11.9$ \\
\hline 6 & 30 & 400 & 20 & 8 & $256.1 \pm 6.8$ \\
\hline 7 & 30 & 400 & 20 & 10 & $312.5 \pm 13.9$ \\
\hline 8 & 30 & 400 & 25 & 9 & $304.5 \pm 9.0$ \\
\hline 9 & 30 & 400 & 30 & 10 & $321.4 \pm 8.9$ \\
\hline 10 & 30 & 400 & 30 & 8 & $264.2 \pm 10.3$ \\
\hline 11 & 30 & 200 & 20 & 9 & $269.2 \pm 18.2$ \\
\hline 12 & 30 & 600 & 30 & 9 & $289.7 \pm 11.5$ \\
\hline 13 & 30 & 600 & 25 & 8 & $278.6 \pm 10.0$ \\
\hline 14 & 30 & 200 & 25 & 8 & $253.6 \pm 12.2$ \\
\hline 15 & 20 & 400 & 30 & 9 & $250.3 \pm 8.0$ \\
\hline 16 & 30 & 400 & 25 & 9 & $298.8 \pm 9.3$ \\
\hline 17 & 30 & 400 & 25 & 9 & $298.4 \pm 14.6$ \\
\hline 18 & 40 & 400 & 25 & 8 & $276.5 \pm 9.2$ \\
\hline 19 & 40 & 400 & 30 & 9 & $278.3 \pm 16.9$ \\
\hline 20 & 30 & 600 & 25 & 10 & $326.5 \pm 9.2$ \\
\hline 21 & 20 & 600 & 25 & 9 & $276.9 \pm 10.0$ \\
\hline 22 & 20 & 400 & 25 & 10 & $320.8 \pm 11.8$ \\
\hline 23 & 40 & 200 & 25 & 9 & $266.8 \pm 8.7$ \\
\hline 24 & 40 & 400 & 20 & 9 & $270.5 \pm 10.4$ \\
\hline 25 & 30 & 400 & 25 & 9 & $298.6 \pm 14.0$ \\
\hline 26 & 30 & 200 & 25 & 10 & $300.2 \pm 10.4$ \\
\hline 27 & 40 & 400 & 25 & 10 & $307.4 \pm 6.9$ \\
\hline 28 & 30 & 400 & 25 & 9 & $302.2 \pm 11.3$ \\
\hline 29 & 20 & 200 & 25 & 9 & $244.8 \pm 11.0$ \\
\hline
\end{tabular}

*Values are expressed as mean \pm SD $(n=3)$. 


\subsection{Electrophoretic analysis}

Sodium dodecyl sulfate-polyacrylamide gel electrophoresis (SDS-PAGE) of SAPC samples were carried out according to reported procedures with slight modifications (Laemmli, 1970) using $12 \%$ separating gel and $4 \%$ stacking gel. The electrophoresis was run at $75 \mathrm{~V}$ in the stacking gel and $150 \mathrm{~V}$ in the separating gel until the tracking dye reached the bottom of the gel. Then, the gels were stained with Coomassie Brilliant Blue G 250.

\subsection{Yield and proximate composition}

Protein, moisture, fat and ash contents of samples were determined according to the AOAC standard procedures (Association of Analytical Communities, 2007). The contents were expressed in $\mathrm{g} / 100 \mathrm{~g}$. Yield of samples were estimated as Equation 2:

Yield $(\%)=\left(\frac{m_{d}}{m_{d e}}\right) \times 100 \%$

Where $m_{d}$ represented as the weight of extracted SAPC (g); $m_{d e}$ represented as the weight of defatted SA $(\mathrm{g})$.

\subsection{Functional properties}

\section{Protein solubility}

The assay was determined according to the reported procedures with slight modifications (Mao \& Hua, 2012). Samples containing two milliliters of aqueous solution $(0.1 \% \mathrm{w} / \mathrm{v})$ were adjusted to different $\mathrm{pH}$ values ranging from 2.0 to $12.0 \mathrm{using} 0.1 \mathrm{~mol} / \mathrm{L} \mathrm{HCl}$ or $0.1 \mathrm{~mol} / \mathrm{L} \mathrm{NaOH}$, and then stirred and vortexed for $30 \mathrm{~min}$. The mixtures were then centrifuged at $10000 \mathrm{r} / \mathrm{min}$ for $10 \mathrm{~min}$. The supernatants were collected and the WSPC was measured. The solubility was calculated as Equation 3:

Solubility $(\%)=\left(\frac{m}{m_{T}}\right) \times 100 \%$

Where $m$ represented as WSPC in supernatant $(\mathrm{mg} / \mathrm{g})$; $m_{T}$ represented as the content of total protein in $\mathrm{SA}(\mathrm{mg} / \mathrm{g})$.

\section{Emulsifying properties}

Evaluation of emulsifying activity index (EAI) and emulsion stability index (ESI) were performed based on the reported procedure (Pearce \& Kinsella, 1978). Samples containing thirty milliliters of solution $(10 \mathrm{~g} / \mathrm{L})$ were mixed with $10 \mathrm{~mL}$ of soybean oil, and were homogenized with an ultrasonic disperser for $2 \mathrm{~min}$ at $200 \mathrm{~W}$. An aliquot of the emulsion $(50 \mu \mathrm{L})$ was immediately pipetted out after homogenization from the bottom at 0 and $10 \mathrm{~min}$ and diluted with $5 \mathrm{~mL} 0.1 \%$ (w/v) sodium dodecyl sulfate (SDS) solution. The absorbance of the diluted emulsion was measured at $500 \mathrm{~nm}$ using UV/VIS spectrophotometer (China, WFZ 754, CO, LTD). EAI and ESI were calculated as Equation 4 and Equation 5 respectively:

$$
\begin{aligned}
& E A I\left(m^{2} / g\right)=\left(\frac{2 \times 2.303 \times A_{0} \times \text { dilution factor }}{C \times \varphi \times 10000}\right) \\
& \operatorname{ESI}(\min )=\left(\frac{A_{0}}{A_{0}-A_{10}}\right) \times \Delta t
\end{aligned}
$$

Where $\mathrm{A}_{0}$ and $\mathrm{A}_{10}$ are the absorbance of analyzes at $0 \mathrm{~min}$ and $10 \mathrm{~min}$ respectively, dilution factor is $100, \mathrm{C}$ is the initial concentration of protein $(\mathrm{g} / \mathrm{mL}), \varphi$ is equal to 0.25 (oil volumetric fraction), $\triangle \mathrm{A}=\mathrm{A}_{0}-\mathrm{A}_{10}$ and $\triangle \mathrm{t}$ is $10 \mathrm{~min}$.

\section{Foaming properties}

Foaming capacity (FC) and foam stability (FS) of samples were determined following a previous method (Turan et al., 2015) with minor modifications. Samples containing solution $(10 \mathrm{~g} / \mathrm{L}, 25 \mathrm{~mL})$ were whipped for $10 \mathrm{~min}$ with an ultrasonic disperser for $2 \mathrm{~min}$ at $200 \mathrm{~W}$. The whipped samples were immediately transferred into a cylinder $(50 \mathrm{~mL})$. The volumes before and after whipping were recorded. The total volume of foam remaining was recorded after $30 \mathrm{~min}$ quiescent period at room temperature. All experiments were conducted with triplicate samples. FC and FS were calculated as Equation 6 and Equation 7 respectively:

$$
\begin{aligned}
& F C(\%)=\left(\frac{V_{1}-V_{2}}{V_{2}}\right) \times 100 \\
& F S(\%)=\frac{V_{3}-V_{2}}{V_{2}} \times 100
\end{aligned}
$$

Where $\mathrm{V}_{1}$ is the volume after whipping, $\mathrm{V}_{2}$ is the volume before whipping, $\mathrm{V}_{3}$ is the volume after standing.

\section{Water and oil holding capacity}

Water holding capacity (WHC) and oil holding capacity $(\mathrm{OHC})$ of samples were determined according to the previous method (Jain \& Anal, 2016). Approximately $25 \mathrm{~mL}$ of distilled water or refined soybean oil were added into pre-weighed centrifuge tubes containing $1 \mathrm{~g}$ of dry sample and subjected to stirring and mixing for $30 \mathrm{~min}$. After being centrifuged at $2000 \mathrm{r} / \mathrm{min}$ for $30 \mathrm{~min}$, the supernatant was discarded and the residue was drained for $15 \mathrm{~min}$ at room temperature and then weighted. WHC and OHC were calculated as the weight of water and oil adsorbed by $1 \mathrm{~g}$ sample.

\subsection{Statistical analysis}

Design-Expert 8.06(State-Ease Inc., Minneapolis, USA) was used for experimental design and data analyses of RSM. Other experiments were performed with SPSS Version 19.0 (Chicago, IL, USA) using ANOVA and Tukey analysis. The statistical differences between samples were measured by the least significant difference (LSD) test. $P<0.05$ was considered to be significant. All experiments were performed in triplicate and SD was calculated. 


\section{Results and discussion}

\subsection{Optimization of the extraction parameters by RSM}

\section{Model fitting}

The fitted quadratic model for WSPC is: $\mathrm{Y}=300.50+$ $8.17 \mathrm{X} 1+12.79 \mathrm{X} 2+0.48 \mathrm{X} 3+27.06 \mathrm{X} 4-3.20 \mathrm{X} 1 \mathrm{X} 2+$ $4.28 \mathrm{X} 1 \mathrm{X} 3-13.68 \mathrm{X} 1 \mathrm{X} 4+8.95 \mathrm{X} 2 \mathrm{X} 3+0.32 \mathrm{X} 2 \mathrm{X} 4+0.17 \mathrm{X} 3 \mathrm{X} 4-$ 18.94 X12 - 13.65 X22 - 16.24 X32 + 3.52X42. Model validity was confirmed by using the lack of fit test, as summarized in Table 2. In the regression model, $\mathrm{Y}$ was highly significant $(\mathrm{P}<0.01)$, and ANOVA for the lack of fit was insignificant $(\mathrm{P}=0.1896)$. This result indicated that this model well fit the experimental data. The coefficient of determination $(\mathrm{R} 2=0.9874)$ obtained for the predicted model indicated a quadratic relationship between $\mathrm{Y}$ and extraction parameters with a good regression coefficient. The most prominent factor affecting WSPC was $\mathrm{pH}$ $\left(\mathrm{X}_{4}\right.$, followed by ultrasonic power $\left(\mathrm{X}_{2}\right)$, extraction time $\left(\mathrm{X}_{1}\right)$, and liquid/solid ratio $\left(\mathrm{X}_{3}\right)$. The quadratic term $\left(\mathrm{X}_{14}, \mathrm{X}_{12}, \mathrm{X}_{22}\right.$, and $\left.\mathrm{X}_{32}\right)$ was highly significant $(\mathrm{P}<0.01)$, and $\mathrm{X}_{1} \mathrm{X}_{3}, \mathrm{X}_{2} \mathrm{X}_{3}$, and $\mathrm{X}_{42}$ terms were moderately significant $(\mathrm{P}<0.05)$. However, other interaction terms were insignificant $(\mathrm{P}>0.05)$.

\section{Analysis of response surface}

A series of three-dimensional (3D) response surface graphs were generated and are presented in Figure $1 \mathrm{a}-\mathrm{f}$, which shows the relationship between WSPC and extraction parameters. According to Figure $1 \mathrm{c}, \mathrm{e}, \mathrm{f}, \mathrm{WSPC}$ increased significantly with the increase of $\mathrm{pH}$ from 8 to 10 . This result was consistent with previous findings that alkaline solvents are the most effective solvent to extract SAPC (Zhang, 2003). As shown in Figure 1 a, d, e, the WSPC of SA increased when ultrasonic power increased from $200 \mathrm{~W}$ to $400 \mathrm{~W}$, which may be attributed to the further breaking of SA cells, leading to the release of more proteins into the liquid/solid system (Tang et al., 2015). However, when the ultrasonic power was further increased from $400 \mathrm{~W}$ to $600 \mathrm{~W}$, the WSPC slowly decreased because the higher ultrasound power generated high-pressure conditions that reduced the solubility of the protein (Zhu et al., 2009). As presented in Figure $1 \mathrm{a}, \mathrm{b}, \mathrm{c}$, WSPC increased rapidly from $20 \mathrm{~min}$ to $30 \mathrm{~min}$. During this period, the cell walls of SA broke gradually, which accelerated the release of proteins. However, with additional time, no obvious increase of WSPC was observed. Similarly, as shown in Figure $1 \mathrm{~b}, \mathrm{~d}, \mathrm{f}$, WSPC increased with the increase of the liquid/solid ratio, and then decreased.

\section{Validation of the model}

The optimum UAE conditions were obtained using Design Expert 8.06 software, and determined as a practical optimum: extraction time of $28 \mathrm{~min}$, ultrasonic power of $450 \mathrm{~W}$, liquid/solid ratio of $25 \mathrm{~mL} / \mathrm{g}$, and $\mathrm{pH}$ of 10 . Verification experiments were performed under optimal conditions $(n=3)$, to further validate the reliability of the theoretical model prediction. The results showed that experimental results for WSPC were very close to the predicted values ( $320.5 \pm 23.6$ and $331 \mathrm{mg} / \mathrm{g}$, respectively), values were not significantly different $(P>0.05)$. Thus, it could be concluded that the established model in this study was appropriate and valid.

\subsection{Comparison of UAE method with CEM}

CEM was performed and compared to UAE to evaluate the extraction efficiency. The extraction time of UAE (28 min) was less significantly than CEM (240 min). The WSPC of extract

Table 2. ANOVA results of water-soluble protein concentration (WSPC).

\begin{tabular}{|c|c|c|c|c|c|}
\hline Source & Sum of squares & Degree of freedom & Mean square & $F$-value & $P$-value \\
\hline Model & 17324.04 & 14 & 1237.43 & 78.68 & $<0.0001$ \\
\hline $\mathrm{X}_{1}($ Extraction time $)$ & 800.33 & 1 & 800.33 & 50.89 & $<0.0001$ \\
\hline $\mathrm{X}_{2}$ (Ultrasonic power) & 1963.52 & 1 & 1963.52 & 124.84 & $<0.0001$ \\
\hline $\mathrm{X}_{3}$ (Liquid/solid ratio) & 2.80 & 1 & 2.80 & 0.18 & 0.6793 \\
\hline $\mathrm{X}_{4}(\mathrm{pH})$ & 8785.84 & 1 & 8785.84 & 558.61 & $<0.0001$ \\
\hline $\mathrm{X}_{1} \mathrm{X}_{2}$ & 40.96 & 1 & 40.96 & 2.60 & 0.1289 \\
\hline $\mathrm{X}_{1} \mathrm{X}_{3}$ & 73.10 & 1 & 73.10 & 4.65 & 0.0490 \\
\hline $\mathrm{X}_{1} \mathrm{X}_{4}$ & 748.02 & 1 & 748.02 & 47.56 & $<0.0001$ \\
\hline $\mathrm{X}_{2} \mathrm{X}_{3}$ & 320.41 & 1 & 320.41 & 20.37 & 0.0005 \\
\hline $\mathrm{X}_{2} \mathrm{X}_{4}$ & 0.42 & 1 & 0.42 & 0.03 & 0.8722 \\
\hline $\mathrm{X}_{3} \mathrm{X}_{4}$ & 0.12 & 1 & 0.12 & 0.01 & 0.9309 \\
\hline $\mathrm{X}_{1}^{2}$ & 2327.27 & 1 & 2327.27 & 147.97 & $<0.0001$ \\
\hline $\mathrm{X}_{2}^{2}$ & 1209.32 & 1 & 1209.32 & 76.89 & $<0.0001$ \\
\hline $\mathrm{X}_{3}^{2}$ & 1711.08 & 1 & 1711.08 & 108.79 & $<0.0001$ \\
\hline $\mathrm{X}_{4}^{2}$ & 80.41 & 1 & 80.41 & 5.11 & 0.0402 \\
\hline Residual & 220.19 & 14 & 15.73 & & \\
\hline Lack of fit & 190.39 & 10 & 19.04 & 2.56 & 0.1896 \\
\hline Pure error & 29.80 & 4 & 7.45 & & \\
\hline Total & 17544.23 & 28 & & $\mathrm{R}^{2}=0.9874$ & \\
\hline
\end{tabular}



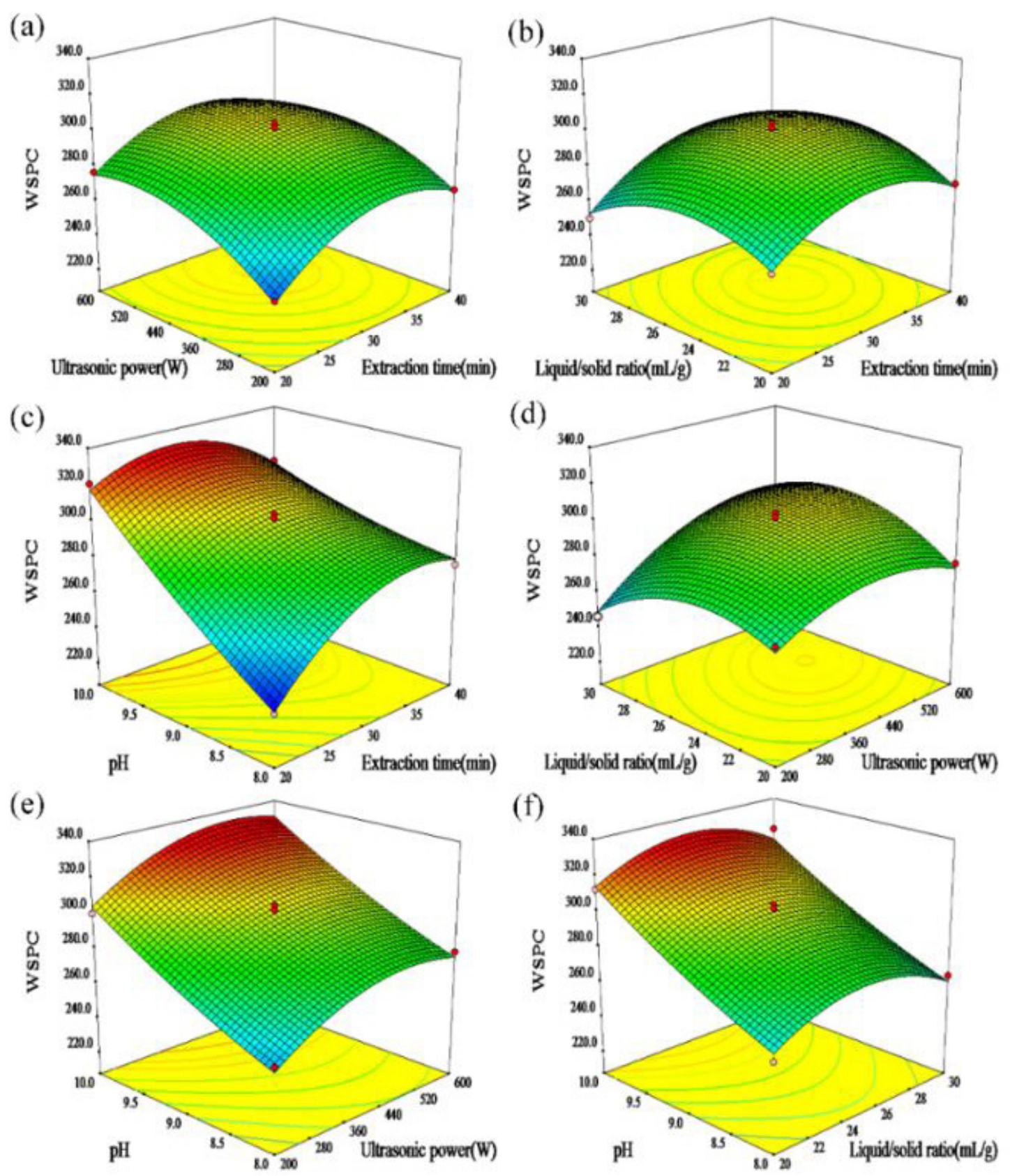

Figure 1. Response surface plots ( $\mathrm{a}, \mathrm{b}, \mathrm{c}, \mathrm{d}, \mathrm{e}$, and $\mathrm{f}$ ) showing the interactive effects of extraction time $\left(\mathrm{X}_{1}\right)$, ultrasonic power $\left(\mathrm{X}_{2}\right)$, liquid/solid ratio $\left(\mathrm{X}_{3}\right)$, and $\mathrm{pH}\left(\mathrm{X}_{4}\right)$ on water-soluble protein concentration (WSPC) using ultrasound-assisted extraction.

obtained by UAE was higher than for CEM $(320.5 \pm 23.6 \mathrm{mg} / \mathrm{g}$, $306.2 \pm 18.9 \mathrm{mg} / \mathrm{g}$ respectively). The better performance with UAE may be due to ultrasound enhanced mass transfer and particle diffusion within the liquid/solid system, as CEM agitation only enhances external mass transfer (Tang et al., 2015).

As shown in Figure 2, the protein species and the molecular weight of proteins in the SAPC samples were determined by SDS-PAGE. The SAPC samples obtained by UAE and CEM contain a variety of protein bands of similar molecular weight (MW) between 10 and $130 \mathrm{kDa}$, based on comparison to a standard composed of a mixture of proteins of known MW.
Further analysis of the composition of the proteins in SAPC and evaluation of the biological activities of SAPC is warranted.

\subsection{Yield and proximate composition}

The yield and proximate composition of defatted SA and SAPC samples were measured and are shown in Table 3. Significant $(P<0.05)$ differences were found in yield, fat, ash, protein, and moisture contents of all samples. The highest yield and protein values were observed in SAPC obtained by the UAE method, and were $24.41 \pm 0.71 \%$ and $92.36 \pm 3.80 \mathrm{~g} / 100 \mathrm{~g}$, respectively. These findings indicate that UAE was the most effective method 
Table 3. Yield and proximate compositions of sheep abomasum protein concentrates (SAPC).

\begin{tabular}{ccrc}
\hline Properties & $\begin{array}{c}\text { Defatted sheep } \\
\text { abomasum }\end{array}$ & Ultrasound-assisted method & Conventional method \\
\cline { 3 - 4 } & & $24.41 \pm 0.71^{\mathrm{a}}$ & $22.46 \pm 0.90^{\mathrm{b}}$ \\
Yield $(\mathrm{g} / 100 \mathrm{~g})$ & $36.74 \pm 1.65^{\mathrm{c}}$ & $92.36 \pm 3.80^{\mathrm{a}}$ & $86.52 \pm 2.74^{\mathrm{b}}$ \\
Protein $(\mathrm{g} / 100 \mathrm{~g})$ & $1.12 \pm 0.04^{\mathrm{a}}$ & $0.81 \pm 0.04^{\mathrm{c}}$ & $0.93 \pm 0.05^{\mathrm{b}}$ \\
Fat $(\mathrm{g} / 100 \mathrm{~g})$ & $5.73 \pm 0.26^{\mathrm{a}}$ & $1.02 \pm 0.10^{\mathrm{c}}$ & $1.31 \pm 0.05^{\mathrm{b}}$ \\
Moisture $(\mathrm{g} / 100 \mathrm{~g})$ & $9.63 \pm 0.98^{\mathrm{a}}$ & $4.24 \pm 0.09^{\mathrm{c}}$ & $6.15 \pm 0.06^{\mathrm{b}}$ \\
Ash $(\mathrm{g} / 100 \mathrm{~g})$ & & & \\
\hline
\end{tabular}

Values are expressed as mean $\pm \mathrm{SD}(\mathrm{n}=3)$.

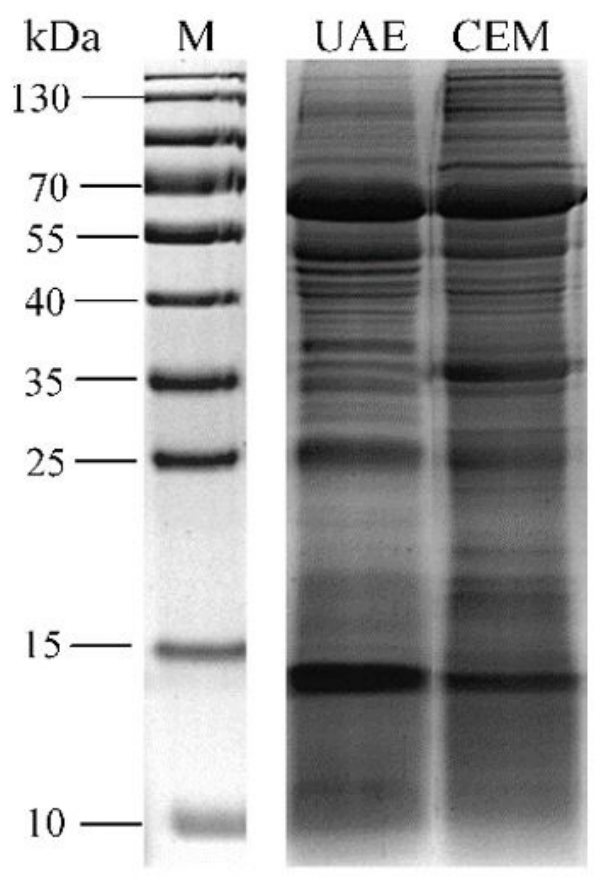

Figure 2. Sodium dodecyl sulfate-polyacrylamide gel electrophoresis (SDS-PAGE) analysis of sheep abomasum protein concentrates (SAPC) obtained by ultrasound-assisted extraction (UAE) and conventional extraction method (CEM) using $12 \%$ separating gel. M, protein standard.

for extraction of SAPC due to the higher WSPC value and better extraction yield within the shortest time.

Means with different letters within the same row indicate significant differences $(P \leq 0.05)$.

\subsection{Functional properties of SAPC}

The protein solubility profile of SAPC over a wide range of $\mathrm{pH}$ values (2.0-12.0) was determined and is shown in Figure 3. There was an observed difference in the solubility of SAPC prepared by UAE and CEM $(P<0.05)$. The poorest solubility of both SAPC samples was observed at $\mathrm{pH}=4$ (isoelectric point), but below and above this $\mathrm{pH}$, the solubility increased, consistent with the report of Gbogouri et al. (2004). At the isoelectric $\mathrm{pH}$, the net charge of the proteins will be small or zero, and the reduced electrostatic repulsive forces of proteins cause protein aggregation and precipitation that decreases solubility (Wu et al.,

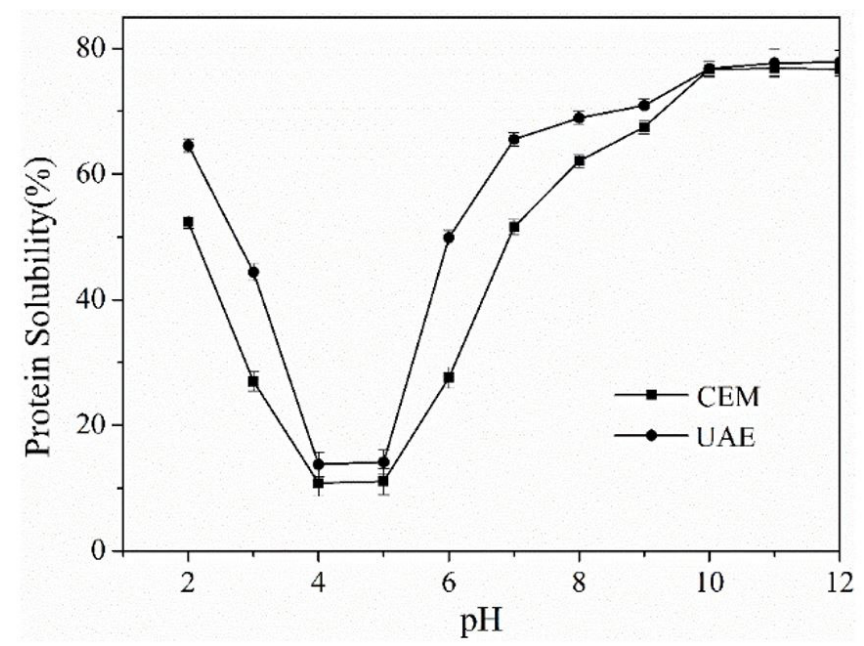

Figure 3. Protein solubility of sheep abomasum protein concentrates (SAPC) at varying $\mathrm{pH}$. CEM, conventional extraction method. UAE, ultrasound-assisted extraction.

2009). At pH 2, the solubility of the SAPC sample prepared using the UAE method was about $64.5 \%$ and that of the conventional method was about $52.4 \%$. With the increase of $\mathrm{pH}$, the solubility of both methods gradually increased, and the solubility of the UAE was always higher than that of CEM, consistent with the report of Jain \& Anal, (2016). The maximum solubilities of SAPC samples were observed at $\mathrm{pH} 12$ with $76.8 \%$ for CEM and $77.8 \%$ for the UAE method. The results indicated that SAPC obtained by UAE method exhibited excellent solubility at alkaline $\mathrm{pH}$, an important qualification for food or medicine formulation.

All other measured functional properties of SAPC are shown in Table 4. In the preliminary experiments, the emulsifying properties and foaming properties could not be reliably determined at $\mathrm{pH} 2.0$ and 5.0, which might be due to the poor solubility of the protein (Chove et al., 2001). Instead, those properties were determined at $\mathrm{pH} 8.0$. The emulsifying properties play an important role in food and medical material processing. EAI is defined as the ability of a protein to form an emulsion by adsorbing oil at the water-oil interface. ESI is defined as the ability to stabilize an emulsion without coalescence or flocculation over a period of time (Jain \& Anal, 2016). The EAI and ESI values of the SAPC sample extracted using UAE method were higher than the values for the sample prepared using CEM $(P<0.05)$. The maximum EAI and ESI values were $42.26 \pm 0.18$ and 82.05 
Bing; Haji Akber; Abulimiti

Table 4. Functional properties of sheep abomasum protein concentrates (SAPC).

\begin{tabular}{ccc}
\hline Properties & \multicolumn{2}{c}{ SAPC } \\
\cline { 2 - 3 } & Ultrasound-assisted method & Conventional method \\
\hline Emulsifying activity index $\left(\mathrm{m}^{2} / \mathrm{g}\right)$ & $42.26 \pm 0.18^{\mathrm{a}}$ & $38.53 \pm 0.14^{\mathrm{b}}$ \\
Emulsion stability index $(\mathrm{min})$ & $82.05 \pm 1.97^{\mathrm{a}}$ & $60.17 \pm 0.96^{\mathrm{b}}$ \\
Foaming capacity (\%) & $23.19 \pm 0.48^{\mathrm{a}}$ & $23.16 \pm 0.08^{\mathrm{a}}$ \\
Foam stability (\%) & $16.44 \pm 1.70^{\mathrm{a}}$ & $12.13 \pm 1.45^{\mathrm{b}}$ \\
Water holding capacity (g/g) & $4.03 \pm 0.05^{\mathrm{b}}$ & $6.43 \pm 0.19^{\mathrm{a}}$ \\
Oil holding capacity (g/g) & $21.20 \pm 1.10^{\mathrm{a}}$ & $16.26 \pm 0.93^{\mathrm{b}}$ \\
\hline
\end{tabular}

Values are expressed as mean $\pm \mathrm{SD}(\mathrm{n}=3)$. Means with different letters within the same row indicate significant differences $(P \leq 0.05)$.

\pm 1.97 respectively. Therefore, SAPC obtained by UAE has better emulsifying properties that should facilitate use in food or medicine applications.

The foaming properties are also important properties in manufacturing food or medicine formulations. FS of SAPC prepared using the UAE method was higher than that using CEM, $16.44 \pm 1.70$ and $12.14 \pm 1.45 \%$ respectively $(P<0.05)$. This difference might be due to the higher protein solubility of the SAPC sample prepared using the UAE method compared to that of the sample prepared by CEM (Suppavorasatit et al., 2011). However, FC of SAPC samples were not significantly different $(P>0.05), 23.19 \pm 0.48$ and $23.16 \pm 0.08 \%$ respectively. Similarly, previous study also showed that foam properties are typically influenced by factors affecting solubility during modification processes (Hou et al., 2017; Zou et al., 2017).

WHC and OHC are important properties that determine the shelf life of products (Wu et al., 2009; Jain \& Anal, 2016). The values of WHC and OHC were significantly different $(P<0.05)$ for the different SAPC samples. SAPC prepared by the UAE method had higher OHC values $(21.20 \pm 1.10 \mathrm{~g} / \mathrm{g})$, but lower WHC values $(6.43 \pm 0.19 \mathrm{~g} / \mathrm{g})$ than those of the SAPC prepared by CEM. These results indicate that the SAPC sample prepared by UAE retained more oil than water, and was also more lipophilic than the material prepared using CEM.

\section{Conclusion}

This is the first report of testing UAE for SAPC extraction. The effects of extraction time, ultrasonic power, liquid/solid ratio, and $\mathrm{pH}$ were investigated using RSM to maximize the WSPC of the extract. The results indicated that UAE technology increased the protein contents and yield but also shortened the extraction time. The SAPC obtained by UAE method showed enhanced functional properties, such as solubility, emulsifying properties, foaming properties, and oil holding capacity as compared to the properties of the extract prepared by CEM. Taken together, the UAE method can be applied as a novel procedure to prepare functional SAPC, a valuable animal protein with potential uses as a pharmaceutical or nutritional ingredients in various food or medicines.

\section{Acknowledgements}

Thanks for financial support to the project of «Supporting Xinjiang 201491160» and 2014 "The light of the western» talent training plan; Thank for the Central Asia Drug Research and Development Center of the Chinese Academy of Sciences and the Training Project of Xinjiang Autonomous Region for Technological Innovation of Youth Talents for financial support.

\section{References}

Association of Analytical Communities - AOAC. (2007). Official Methods of Analysis (18th ed.). Gaithersburg: AOAC International.

Chen, Y. X. (1982). Biochemical new drug-Lamb abomasum membrane extractor. Organ Biochemical Medicine, 2, 39-40.

Chittapalo, T., \& Noomhorm, A. (2009). Ultrasonic assisted alkali extraction of protein from defatted rice bran and properties of the protein concentrates. International Journal of Food Science \& Technology, 44(9), 1843-1849. http://dx.doi.org/10.1111/j.13652621.2009.02009.x.

Chove, B. E., Grandison, A. S., \& Lewis, M. J. (2001). Emulsifying properties of soy protein isolate fractions obtained by isoelectric precipitation. Journal of the Science of Food and Agriculture, 81(8), 759-763. http://dx.doi.org/10.1002/jsfa.877.

Dong, X. Y., Guo, L. L., Wei, F., Li, J. F., Jiang, M. L., Li, G. M., Zhao, Y. D., \& Chen, H. (2011). Some characteristics and functional properties of rapeseed protein prepared by ultrasonication, ultrafiltration and isoelectric precipitation. Journal of the Science of Food and Agriculture, 91(8), 1488-1498. http://dx.doi.org/10.1002/jsfa.4339. PMid:21384382.

Gbogouri, G., Linder, M., Fanni, J., \& Parmentier, M. (2004). Influence of hydrolysis degree on the functional properties of salmon by products hydrolysates. Journal of Food Science, 69(8), 615-619. http://dx.doi. org/10.1111/j.1365-2621.2004.tb09909.x.

Hou, F. R., Ding, W. H., Qu, W., Oladejo, A. O., Xiong, F., Zhang, W. W., He, R. H., \& Ma, H. L. (2017). Alkali solution extraction of rice residue protein isolates: influence of alkali concentration on protein functional, structural properties and lysinoalanine formation. Food Chemistry, 218, 207-215. http://dx.doi.org/10.1016/j. foodchem.2016.09.064. PMid:27719899.

Jain, S., \& Anal, A. K. (2016). Optimization of extraction of functional protein hydrolysates from chicken egg shell membrane (ESM) by ultrasonic assisted extraction (UAE) and enzymatic hydrolysis. Lebensmittel-Wissenschaft + Technologie, 69, 295-302. http://dx.doi. org/10.1016/j.lwt.2016.01.057.

Jodayree, S., Smith, J. C., \& Tsopmo, A. (2012). Use of carbohydrase to enhance protein extraction efficiency and antioxidative properties of oat bran protein hydrolysates. Food Research International, 46(1), 69-75. http://dx.doi.org/10.1016/j.foodres.2011.12.004.

Laemmli, U. K. (1970). Cleavage of structural proteins during the assembly of the head of bacteriophage T4. Nature, 227(5259), 680681. http://dx.doi.org/10.1038/227680a0. PMid:5432063. 
Li, H., Zhang, Z., He, D., Xia, Y., Liu, Q., \& Li, X. (2017). Ultrasoundassisted aqueous enzymatic extraction of oil from perilla seeds and determination of its physicochemical properties, fatty acid composition and antioxidant activity. Food Science and Technology (Campinas), 37(Suppl 1), 71-77. http://dx.doi.org/10.1590/1678-457x.29116.

Li, J. H., \& Chen, S. H. (1987). Preparation and determination of activity of pharmaceutical pepsin from abomasum of young sheep. Journal of China Pharmaceutical University, 18(1), 60-63.

Mao, X. Y., \& Hua, Y. (2012). Composition, structure and functional properties of protein concentrates and isolates produced from walnut (Juglans regia L.). International Journal of Molecular Sciences, 13(2), 1561-1581. http://dx.doi.org/10.3390/ijms13021561. PMid:22408408.

Martínez-Alvarez, O., Chamorro, S., \& Brenes, A. (2015). Protein hydrolysates from animal processing by-products as a source of bioactive molecules with interest in animal feeding: a review. Food Research International, 73, 204-212. http://dx.doi.org/10.1016/j. foodres.2015.04.005.

Mora, L., Reig, M., \& Toldrá, F. (2014). Bioactive peptides generated from meat industry by-products. Food Research International, 65, 344-349. http://dx.doi.org/10.1016/j.foodres.2014.09.014.

Pearce, K. N., \& Kinsella, J. E. (1978). Emulsifying properties of proteins: evaluation of a turbidimetric technique. Journal of Agricultural and Food Chemistry, 26(3), 716-723. http://dx.doi.org/10.1021/jf60217a041.

Queiroz, A. L. M., Araújo, A. R. R., Pacheco, M. T. B., \& Madruga, M. S. (2017). Potential use of goat viscera to obtain protein hydrolysates. Lebensmittel-Wissenschaft + Technologie, 84, 832-837. http://dx.doi. org/10.1016/j.lwt.2017.06.049.

Rocha, J. C. G., Procópio, F. R., Mendonça, A. C., Vieira, L. M., Perrone, I. T., Barros, F. A. R., \& Stringheta, P. C. (2017). Optimization of ultrasound-assisted extraction of phenolic compounds from jussara (euterpe edulis m.) and blueberry (vaccinium myrtillus) fruits. Food Science and Technology (Campinas), 38(1), 45-53. http://dx.doi. org/10.1590/1678-457x.36316.
Suppavorasatit, I., De Mejia, E. G., \& Cadwallader, K. R. (2011). Optimization of the enzymatic deamidation of soy protein by protein-glutaminase and its effect on the functional properties of the protein. Journal of Agricultural and Food Chemistry, 59(21), 11621-11628. http://dx.doi.org/10.1021/jf2028973. PMid:21954863.

Tang, W. L., Zhang, M., \& Fang, Z. X. (2015). Optimization of ultrasoundassisted-extraction of porcine placenta water-soluble proteins and evaluation of the antioxidant activity. Journal of Food Science and Technology, 52(7), 4042-4053. http://dx.doi.org/10.1007/s13197014-1444-1. PMid:26139870.

Toldrá, F., Aristoy, M. C., Mora, L., \& Reig, M. (2012). Innovations in value-addition of edible meat by-products. Meat Science, 92(3), 290 296. http://dx.doi.org/10.1016/j.meatsci.2012.04.004. PMid:22560456.

Turan, D., Capanoglu, E., \& Altay, F. (2015). Investigating the effect of roasting on functional properties of defatted hazelnut flour by response surface methodology (RSM). Lebensmittel-Wissenschaft + Technologie, 63(1), 758-765. http://dx.doi.org/10.1016/j.lwt.2015.03.061.

Wu, H. W., Wang, Q., Ma, T. Z., \& Ren, J. J. (2009). Comparative studies on the functional properties of various protein concentrate preparations of peanut protein. Food Research International, 42(3), 343-348. http://dx.doi.org/10.1016/j.foodres.2008.12.006.

Zhang, F. X. (2003). Studies on the extraction, separation and characterization of the kid chymosin. China: Shanxi Normal University.

Zhao, X. M. (2011). C.N. Patent No. CN101264106B. China: State Intellectual Property Office.

Zhu, K. X., Sun, X. H., \& Zhou, H. M. (2009). Optimization of ultrasound-assisted extraction of defatted wheat germ proteins by reverse micelles. Journal of Cereal Science, 50(2), 266-271. http:// dx.doi.org/10.1016/j.jcs.2009.06.006.

Zou, Y., Xu, P. P., Li, P. P., Cai, P. P., Zhang, M. H., Sun, Z. L., Sun, C., Xu, W. M., \& Wang, D. Y. (2017). Effect of ultrasound pre-treatment on the characterization and properties of collagen extracted from soft-shelled turtle (Pelodiscus sinensis). Lebensmittel-Wissenschaft + Technologie, 82, 72-81. http://dx.doi.org/10.1016/j.lwt.2017.04.024. 